\title{
THE TRACE FOSSIL Gyrochorte: ETHOLOGY AND PALEOECOLOGY
}

\author{
Jordi M. de GIBERT' and Jacob S. BENNER ' \\ ' Departament d`Estratigrafia i Paleontologia. Facultat de Geologia. Universitat de \\ Barcelona. Martí Franquès s/n. 08028 Barcelona. España. E-mail: gibert@geo.ub.es \\ = Department of Geology and Geophysics, University of Utah. 135 South 1460 East \\ Room 719. Salt Lake City. Utah 84112-0111.
}

\begin{abstract}
Gibert, J.M. de and Benner, J.S. 2002. The trace fossil Gyrochorte: ethology and paleoecology. ILa pista fósil
\end{abstract} Gyrochorte: etología y paleoecología.l Revista Española de Paleontología, 17(1), 1-12. ISSN 0213-6937.

\begin{abstract}
Specimens of the trace fossil Grochorte from the Ordovician, Jurassic and Cretaceous of Utah, and the Pliocene of Spain are described. These occurrences expand the stratigraphic range of the ichnogenus, and allow for a reexamination of this paleoenvirommentally sensitive and puzzling trace fossil. The recognition of the penetrative characteristic of the trace is essential for a correct identification, as some trace fossils have been erroneously ascribed to Gyrochorte in the past. The producer must have been a detritus-feeding worm-like animal, probably an annelid, that created a bilobed, vertically penetrating and sometimes plaited meandering trace. Gyrochorte typically occurs in sandy facies in moderately energetic nearshore and shallow marine paleoenvironments in association with other trace fossils, usually pascichnia and fodinichnia.
\end{abstract}

Keywords: Trace fossils, Gyrochorte, ethology.

\section{RESUMEN}

Se describen especímenes de la pista fósil Gyrochorte del Ordovícico, Jurásico y Cretácico de Utah (Estados Unidos) y del Plioceno de España. Estos hallazgos extienden el rango estrátigráfico del icnogénero y permiten reevaluar la interpretación de este icnofósil y su significado paleoambiental. El reconocimiento del carácter penetrativo característico de este icnofósil es esencial para su correcta identificación. El productor debió de ser un animal vermiforme detritívoro, probablemente un anélido. Gyrochorle aparece típicamente en facies arenosas depositadas en medios marinos someros de energía moderada asociado a otras pistas, normalmente pascichnia y fodinichnia.

Palabras clave: Pistas fósiles, Gyrochorte, etología.

\section{INTRODUCTION}

The trace fossil Gyrochorte Heer, 1865 is a frequently encountered ichnogenus in the fossil record, particularly in Mesozoic strata. However, some authors who have reported Gyrochorte did not consider its characteristic taphonomic and preservational features, resulting in some confusion and frequent misuse of the ichnotaxon. A complete Gyrochorte specimen commonly is preserved as a bilobate positive epirelief with a corresponding negative hyporelief. These two semireliefs represent the top and bottom features of a more complex wall-like burrow that is preserved only occasionally in full relief and only in very particular sediment types (e.g., mica-rich sand) does it clearly exhibit its internal structure.

Recent discoveries of Gyrochorte by the authors in strata of different ages (Ordovician, Jurassic, Cretaceous and Pliocene) in Utah and Spain allow us to re-examine the ichnogenus. The purposes of this paper are: 1) to describe the new material, 2) to re-examine the constructional features of the ichnogenus in order to discuss its ethological significance and to establish the most likely tracemaker, 3) to analyze its paleoenvironmental distribution, and 4) to interpret the paleoecology of the tracemaker.

\section{SYSTEMATIC ICHNOLOGY}

\section{Grochorte Heer, 1865}

\section{Emended diagnosis}

Wall-like burrow with a top part (positive epirelief) consisting of two convex lobes with a median furrow and 
a bottom part (negative hyporelief) consisting of two grooves and a median ridge (Fig. 1). The lobes on the top (and more rarely the grooves at the base) commonly exhibit transverse meniscus-like discontinuities and often obliquely aligned plaits. The internal structure (when recognizable) is constituted of repetitive biconvex-up modular units (spreiten). The burrow exhibits an irregular meandering or arcuate course, but more rarely it can be straight or gently curved. It is typically preserved as epichnial bilobate ridges associated with equivalent hypichnial bilobate grooves, both following the same path and corresponding to the same burrow. More rarely preserved as full reliefs (endichnia).

\section{Gyrochorte comosa Heer, 1865}

Figs. 1-7

\section{Material and localities}

The material is stored in the University of Utah Ichnology Collection (UUIC). Specimens from eight localities have been studied: Skull Rock Pass, Lower Ordovician, Utah (UUIC 1034-1037, 1073); Fossil Mountain, Lower Ordovician, Utah (UUIC 648-649); Nephi, Middle Jurassic, Utah (UUIC 984-1022, 1024); San Rafael Swell, Middle Jurassic, Utah (UUIC 961, 963, 965, 10561057); Gunlock, Middle Jurassic, Utah (UUIC 1025-1027); Hanna, Middle Jurassic, Utah (UUIC 1028); Spring Canyon, Upper Cretaceous, Utah (UUIC 1031-1033); Sant Onofre, Lower Pliocene, Spain (UUIC 1029-1030). A short description of the situation of this localities is given in Appendix 1.

\section{Description}

The studied Gyrochorte are between 1 and $4.5 \mathrm{~mm}$ wide and they are commonly preserved as epireliefs with their corresponding hyporeliefs in sandstone or grainstone layers between a few milimeters and 2 centimeters thick. The oblique spreiten that constitute the internal structure of the burrows have been recognized only in Ordovician specimens from Skull Rock Pass (Figs. 2.A-2.B). In these specimens the three main vertical planes of the burrow (the two lateral and the medial) have acted as preferential breakage and erosional discontinuities. In the rest of the material, the penetrative character of the structure can be recognized by observing bilobate semireliefs on intermediate laminae between the epireliefs and hyporeliefs of the same specimen (Fig. 7.A). The Ordovician Gyrochorte are usually straight or gently curved (Fig. 2), while the Mesozoic and Neogene specimens are irregularly sinuous and often form loops (Figs. 3-7). The epireliefs exhibit frequent sudden changes in direction that are absent or less pronounced in the corresponding hyporeliefs, which usually show less winding morphologies (Figs. 3.C-3.F, 4.E-4.F). Figure 5 shows the differences between the hyporeliefs and epireliefs of some Jurassic specimens. Crosscutting is common in all of the material. The lobes in most epireliefs show crude transverse meniscus-like striae, which are the external expression of the internal spreiten. A few specimens exhibit very well defined sets of double plaits bounded by chevron-like scars (Figs.

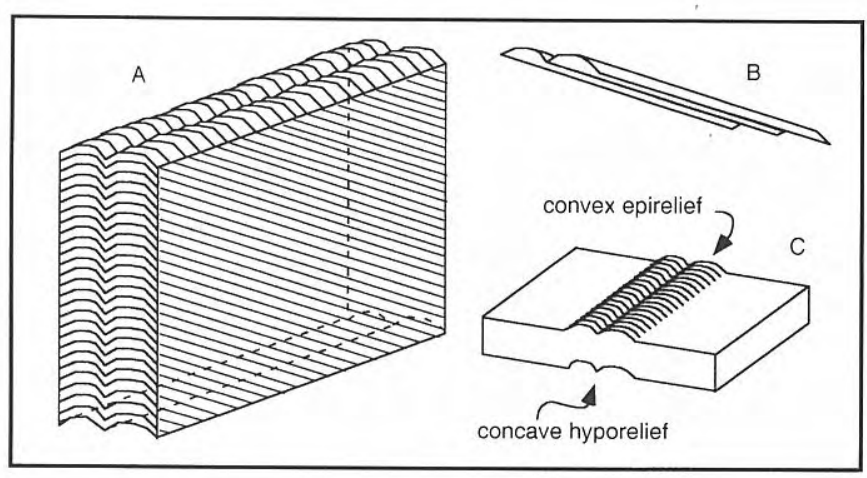

Figure 1. A. Constructional model of Gyrochorte. B. Morphology of an individual spreite. C. Typical preservation of Gyrochorte.

4.A, 4.B). The hyporeliefs occasionally show the meniscuslike structures (Figs. 4.D, 4.F), but they are more commonly smooth.

\section{Discussion}

The most important characteristic for a correct identification of Gyrochorte is the recognition of the vertical dimension of the burrow. This can be observed by finding associated convex epireliefs and their corresponding concave hyporeliefs in the same beds, or by the observation of the structure in full relief. Aulichnites Fenton and Fenton, 1937, is a convex bilobate epichnial trail, but it lacks the vertical dimension and the lobes are smooth. Several authors have designated bilobate epichnial positive trails as possible Gyrochorte (Hakes, 1976; Walter et al., 1989), but the attribution is doubtful without the corresponding hyporeliefs. Several other trace fossils that are hypichnial bilobate ridges also have been assigned erroneously to Gyrochorte, and most of them probably correspond to the ichnogenus Protovirgularia (Macsotay, 1967; Ksiazkiewicz, 1970, 1977; Pickerill, 1980; Crimes et al., 1981). Frey and Chowns' (1972) Silurian Gyrochorte from Georgia are not Gyrochorte but quadrilobate trilobite trails (A. Rindsberg and A. Martin, oral communication).

Several described ichnospecies of Gyrochorte do not belong to the ichnogenus. "Gyrochorte" carbonaria Seilacher,1954, common in continental settings (Pollard, 1988), is not real Gyrochorte (Seilacher, 1963; Häntzschel, 1975). Gyrochorte robusta Ghare and Kulkarni, 1986 was erected on the basis of its greater width when compared to $G$. comosa. However, size must be used cautiously as an ichnotaxobase, and if used, size criteria require some sort of statistical data to support them (Pickerill, 1994). On the other hand, the size range given by Ghare and Kulkarni (1986) for G. robusta (6-9 $\mathrm{mm}$ ) falls in the range known for $G$. comosa. $G$. burtani, $G$. imbricata and $G$. obliterata, which were erected by Ksiazkiewicz (1977), are positive hyporeliefs attributed by Uchman (1998) to several ichnospecies of Protovirgularia. Gyrochorte zigzag Seilacher and Alidou, 1988 from the Silurian of Benin shares some characters with G. comosa (backfill, preservation as correlative 

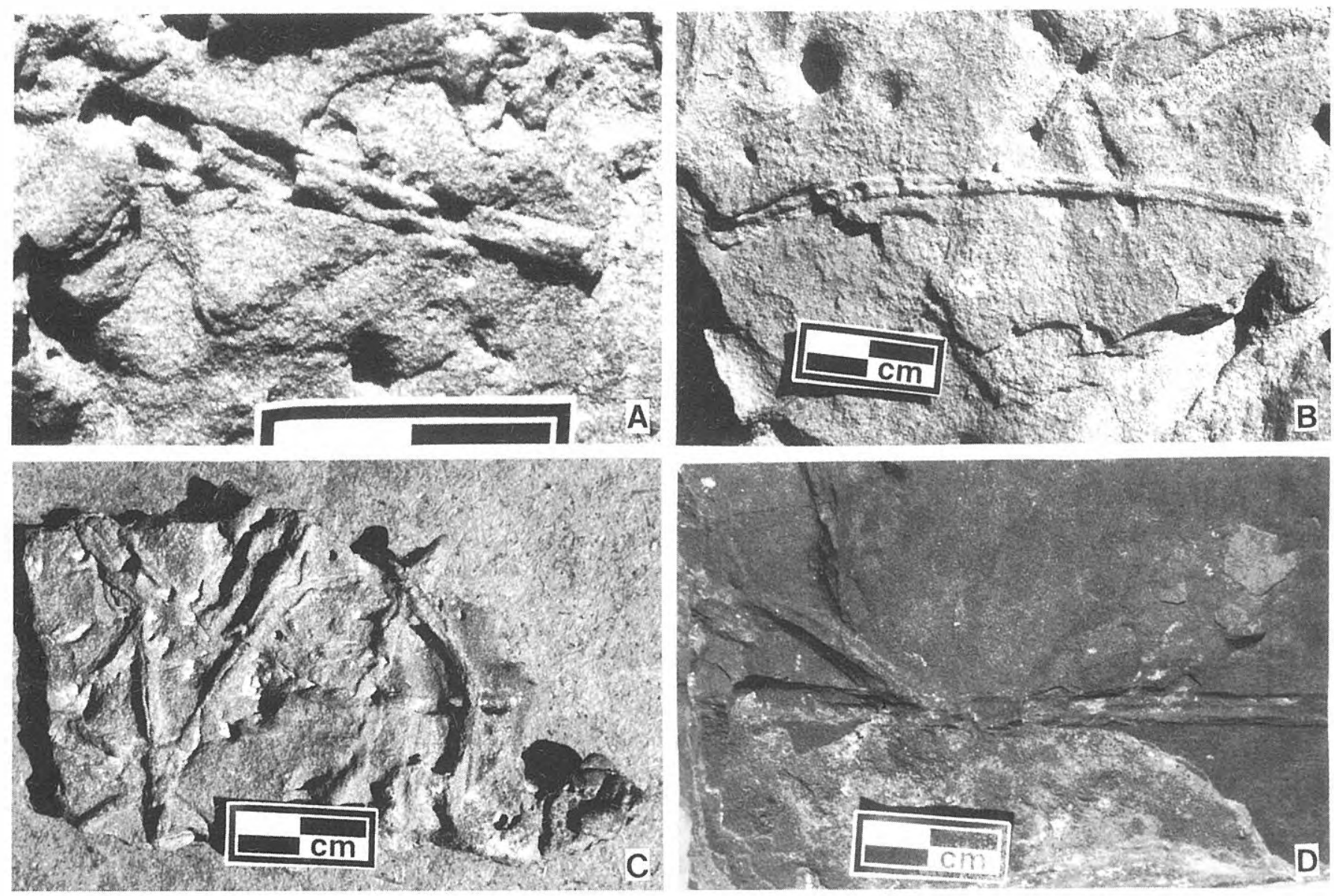

Figure 2. Ordovician Gyrochorte. A. Partly weathered specimen from Skull Rock Pass showing internal oblique discontinuities (UUIC 1037). B. Specimen from Skull Rock Pass displaying the double-arched oblique spreiten (UUIC 1073). C. Several crosscutting Gyrochorte from Skull Rock Pass (UUIC 1035). D. Specimen from Fossil Mountain exhibiting the typical very straight morphology of Ordovician Gyrochorte (UUIC 648).

positive epireliefs and negative hyporeliefs) but also important differences (no bilobate character). Seilacher and Alidou (1988) tentatively assigned the new ichnospecies to the ichnogenus Gyrochorte. We consider that the differences are important enough to assign this ichnospecies to a new and different ichnogenus.

The material described here from the Ordovician apparently exhibits straighter paths than the Mesozoic and Cenozoic specimens. New findings should help to determine if this difference is consistent enough to serve as an ichnotaxobase at the ichnospecific level.

Stratigraphic distribution: Lower Ordovician-Pliocene (see Table 1), being particularly abundant in the Jurassic and Cretaceous.

\section{CONSTRUCTION, ETHOLOGY AND TRACEMAKER}

Several authors have addressed the problem of the ethology and biology of Gyrochorte. Weiss (1941) and later Seilacher (1955) interpreted the trace as being produced by a worm-like organism burrowing obliquely through the sediment (see Seilacher, 1955, fig, 2b, p. 380). Fuchs (1895) pointed to the similarity of the epireliefs of Gyrochorte with collapsed tunnels created by modern amphipod crustaceans that had been described by Hancock (1858). Hallam (1970) points out that this interpretation cannot explain the vertical dimension of Gyrochorte. Heinberg (1973) described for first time the internal structure of the ichnofossil. The material described by Heinberg (1973) from the Lower Cretaceous of Greenland is found in extremely mica-rich sandstone, allowing the unusual preservation of the internal structure of the fossil trace. Heinberg's material revealed that Gyrochorte is constituted by oblique double-arched convex-up spreiten (what he called the "modular unit"). The spreiten repeat vertically and are responsible for the bilobate morphology of the epireliefs and hyporeliefs. In transverse section, Gyrochorte reveals the vertical stacking of the double ridge observed in the semireliefs (Fig. 1). These features had never been observed in other material, as the absence of flat grains did not allow their preservation. However, the Ordovician material from Skull Rock Pass described in this paper allows us to recognize some of the internal features of Gyrochorte and confirms Heinberg's observations (Figs. 2.A, 2.B). 

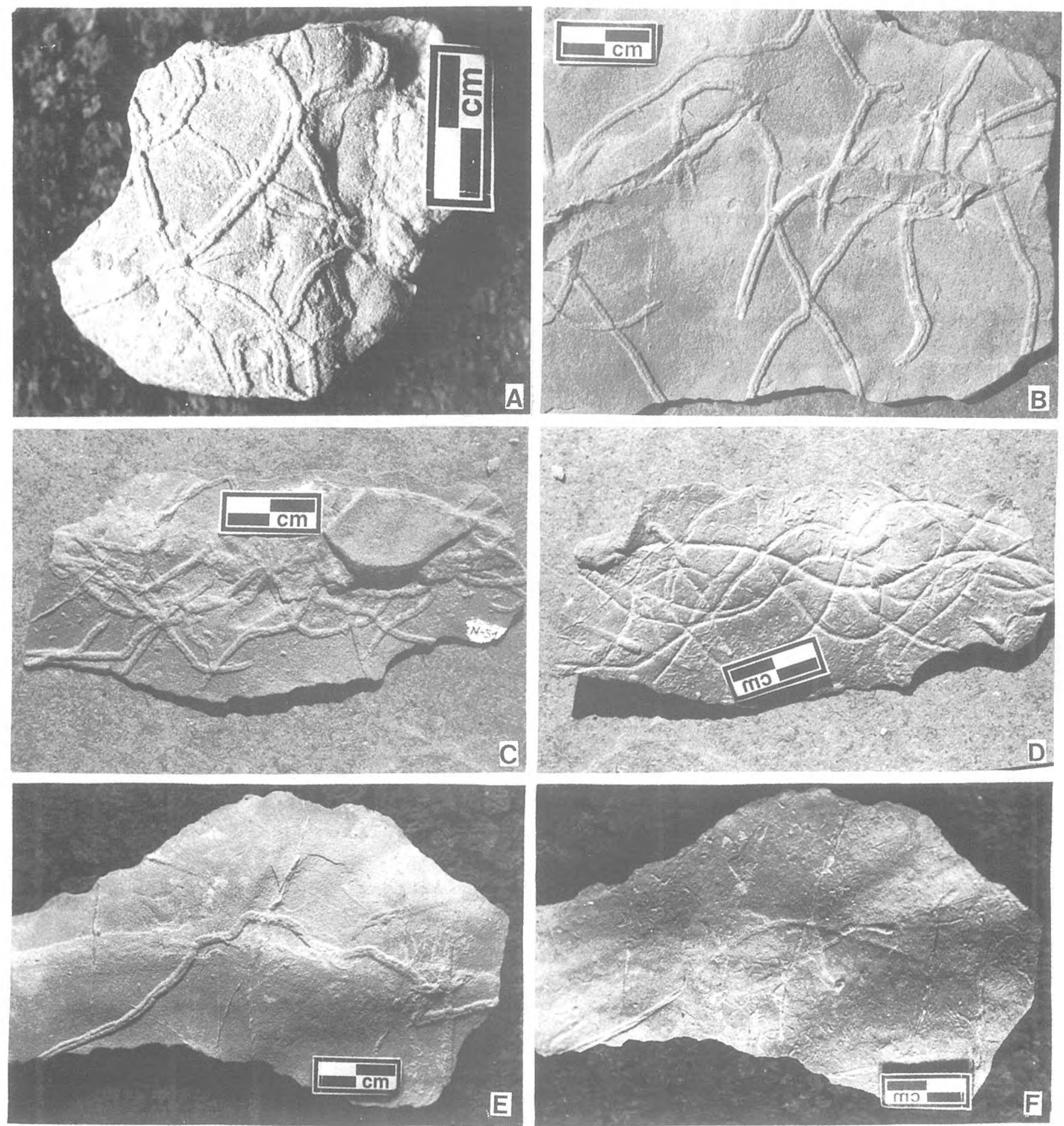

Figure 3. Gyrochorte from the Middle Jurassic Arapien Shale in Nephi. A-B. Crowded occurrences with numerous crosscutting burrows (epireliefs) (UUIC 940 and 1022). C-D. positive epireliefs (C) and corresponding negative hyporeliefs (D) of specimen UUIC 986. E-F. sharply bent positive epirelief (E) and corresponding smoothly curved hyporelief (F) (UUIC 988). D and F were printed in reverse to orient them in the same manner as C and E.

The spreiten can only be explained by active digging of the sediment and movement of the grains around the body of the producer. The double-arch morphology resulted from the displacement of the grains from the frontal and lower part of the body to the back along the sides. This digging activity resulted in forward movement of the animal but oblique to the axis of its body (Fig. 8). The greater irregular pattern of the epireliefs compared to the corresponding hyporeliefs observed in the Jurassic material of Utah, also pointed out by other authors (e.g., 

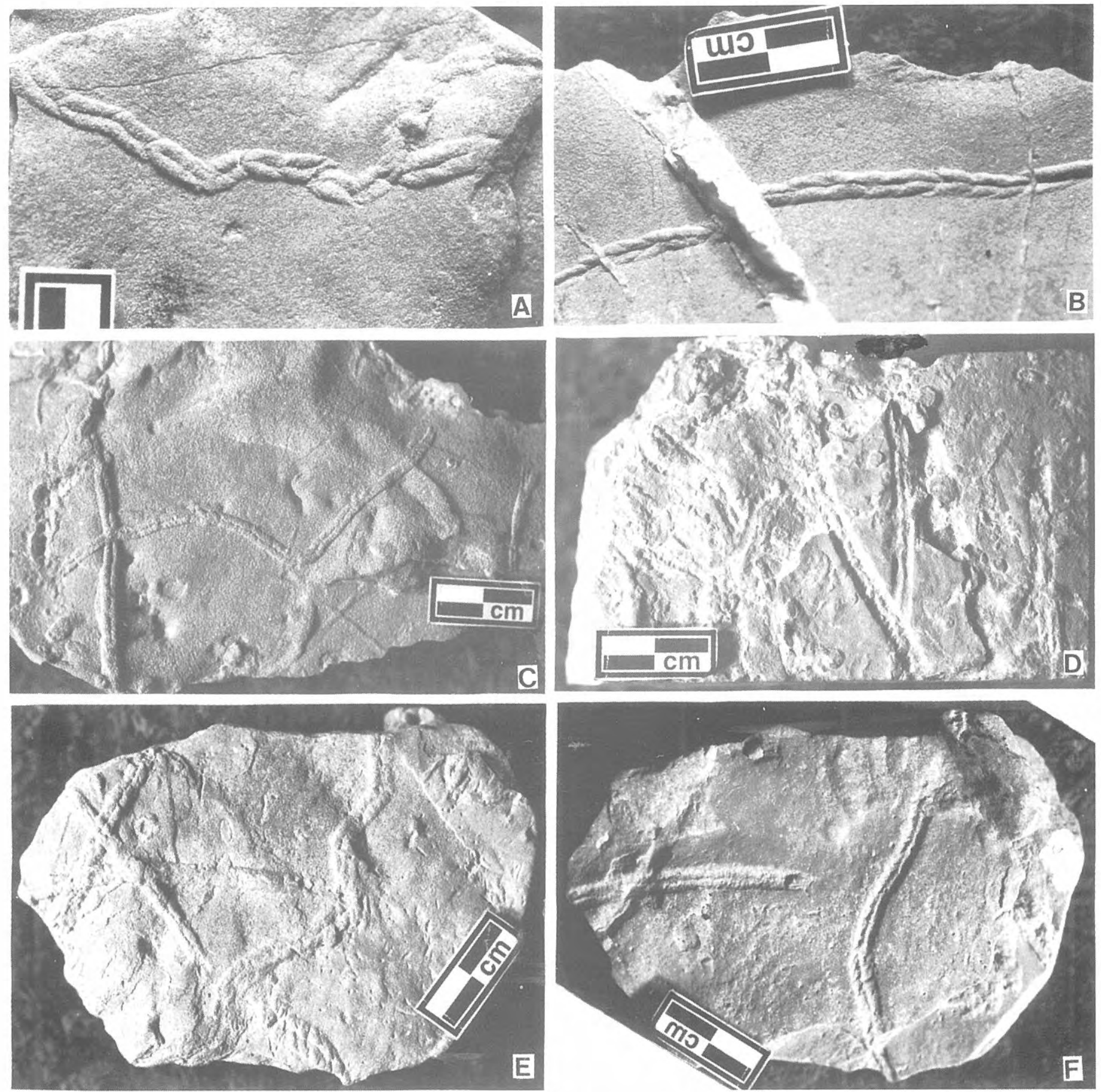

Figure 4. Gyrochorte from the Middle Jurassic of Utah. A-B. Epireliefs from Nephi displaying well-preserved plaited structure (UUIC 987 and 1021). C. Epirelief from Nephi showing well defined meniscus-like marks (UUIC 989). D. Hyporeliefs with well-defined lobes and transverse marks from the Carmel Formation in the San Rafael Swell (UUIC 965). E-F. Epirelief (E) and hyporelief (F) of specimen UUIC 1025 showing the less irregular path of the second. F was printed in reverse to orient the sample in the same manner as E.

Weiss, 1941), is consistent with this constructional model and not with the "collapsed tunnel" model described by Hallam (1970). The lower part of the burrower's body followed a more regular course, and the upper part of the body, while closer to the surface where the sediment would have been looser and easier to burrow, could have followed a more irregular path. The plaited structure that is observed occasionally (Figs. 4.A, 4.B), often is associated with sudden changes of direction, and it probably corresponds to moments when the animal stopped its advance through the sediment. Hence, the internal and external features of Gyrochorte are consistent with the interpretation of Weiss (1941) and Seilacher (1955). The obliquely-burrowing worm interpretation has been followed by most later authors (e.g., Pemberton and Frey, 1984; Dam, 1990; Powell, 1992). 


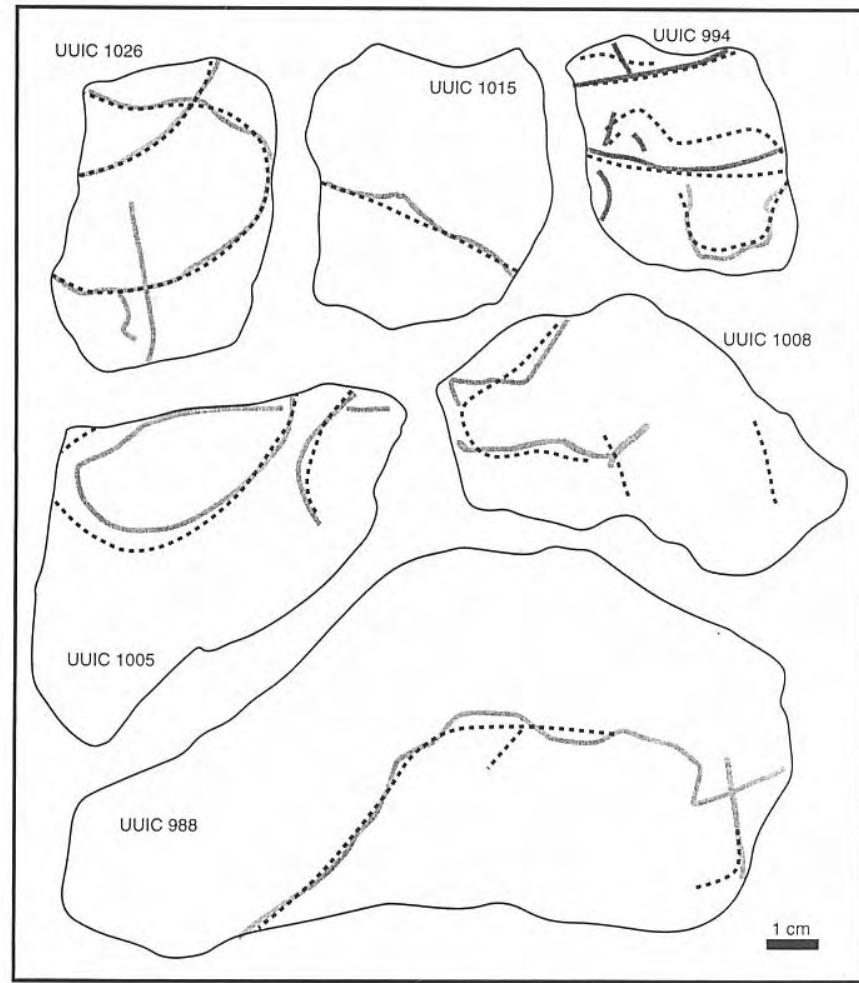

Figure 5. Superposition of epireliefs (gray lines) and hyporeliefs (discontinuous lines) of several specimens from Nephi, showing the more irregular pattern of the epireliefs.

There is no known modern equivalent of a behavior similar to that exhibited by Gyrochorte. Some organisms, such as the tube-bearing polychaete Pectinaria and some scaphopod mollusks, are known to burrow with the main axis of their bodies perpendicular or steeply oblique to the direction of movement, producing a wall-like area of disturbed sediment (Dinamani, 1964; Schäfer, 1972; Ronan, 1977; Bromley, 1996). However, the resulting biogenic structure is produced by plowing the tube or the shell through the sediment, and although this behavior could create a double ridge feature on the surface and a median discontinuity plane, it is unlikely that it could create an internally organized spreiten structure with sharp outer boundaries like those of Gyrochorte. Heinberg and Birkelund (1984) have suggested a caudofoveate aplacophoran as a possible producer for Gyrochorte. However, little is known about the burrowing behavior of these mollusks to support this interpretation. The only burrowing activity described for this group is the construction of vertical burrows (Barnes et al., 1993). The Gyrochorte tracemaker must have been a worm-shaped animal with bilateral symmetry and bearing some sort of organs along the body that enabled it to manipulate and move the sediment. An annelid is a good candidate supported by several authors (Weiss, 1941; Heinberg, 1973; Karaszewski, 1973), as most other worms lack any external anatomical elements that could be used to move grains around their bodies. The vermiform morphology of the burrower is supported by the description by Stanley and Pickerill (1998) of
Ordovician Gyrochorte that is intergradational with Planolites (see also figure 1.3, p. 24 in Pickerill, 1994).

If the assignment of a possible tracemaker for Gyrochorte is not an easy task, then the interpretation of its behavioral significance is, at least, equally difficult. The oblique burrowing behavior deduced from the internal structure of Gyrochorte is very unusual. It implies considerable effort, suggesting that the animal was not simply moving but also obtaining some sort of benefit from this behavior. The irregularly meandering path suggests that the animal was actively searching for food. Heinberg (1973) suggested that the peculiar behavior of the Gyrochorte producer was to bring the animal into contact with as much food as possible while using as little energy as possible, and so, he interpreted the trace as produced by a deposit feeder.

\section{PALEOECOLOGY AND PALEOENVIRONMENT}

\section{ORDOVICIAN}

The section in Skull Rock Pass (Utah) is part of the Filmore Formation (Hintze, 1951, 1973). These strata consist of shallow subtidal to intertidal storm-deposited and fair-weather sediments (Dattilo, 1993). Study of bioturbation structures (Benner, 2000) shows that they are abundant and diverse through the section, including Thalassinoides, Planolites, Teichichnus, Chondrites, Phycodes and Gyrochorte. Gyrochorte comosa occurs in the facies designated by Dattilo (1993) as "calcisiltite and calciarenite". This facies is generally fine-grained, thinly bedded, internally thinly laminated (planar, hummocky and more rarely ripples), and it is interbedded with shales or wavy-laminated mudstones. Dattilo (1993) interpreted this facies as deposited by short-term events, probably storms, in the lower shoreface.

The other Ordovician Gyrochorte studied in this paper come from the Kanosh Shale in Fossil Mountain, Utah. This formation is a mixed clastic and carbonate sequence deposited on a shallow marine shelf (Hintze, 1973; McDowell, 1988). The facies containing Gyrochorte are fine-grained, few centimeter thick, laminated sandstones interpreted as event beds, probably deposited by storms.

\section{JURASSIC}

Gyrochorte from the Middle Jurassic localities of Utah were produced in a shallow epicontinental sea that occupied most of central Utah during the Middle Jurassic (Imlay, 1980).

The section in Nephi consists of evaporites, micritic carbonates and mixed carbonate-clastic grainstones of the Arapien Shale. Picard and Uygur (1982) and Lord (1985) interpreted the formation as having formed in a shallow storm-dominated shelf. Gyrochorte is very abundant in the grainstones that typically are a few centimeters thick and exhibit ripple lamination and more rarely parallel cross-lamination. These beds are interpreted as tempestites (Lord, 1985). Other trace fossils that occur in 

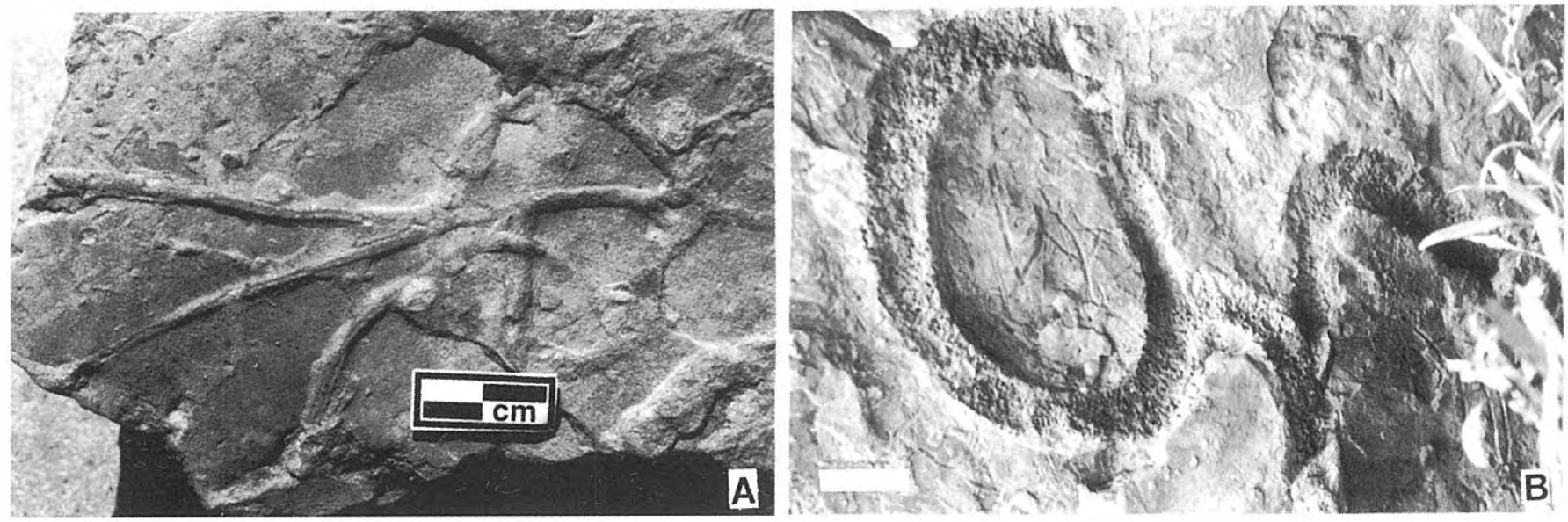

Figure 6. Gyrochorte from the Cretaceous of Spring Canyon. A. Detail of three specimens (epireliefs) (UUIC 1033). B. Abundant Gyrochorte associated with Ophiomorpha irregulaire (field specimen). Scale bar=5 $\mathrm{cm}$.

this facies are Planolites, Lockeia, Palaeophycus, Nereites, and Asteriacites (Gibert and Ekdale, in press).

The presence of Gyrochorte in the Carmel Formation in the San Rafael Swell was recorded by Gibert and Ekdale (1999) in a section constituted by subtidal to supratidal carbonates, siliciclastics and evaporites. Gyrochorte is locally abundant in few-centimeter thick, cross-laminated to rippled sandstone and grainstone beds interpreted as deposited by storms. Gibert and Ekdale (1999) suggested hypersaline environments for the Carmel Formation from the characteristics (size, diversity, intensity of bioturbation) of the trace fossil assemblages. Gyrochorte occurs associated with other trace fossils, such as Chondrites, Planolites, Lockeia, Protovirgularia, and Teichichnus.

Smail and Wilson (1993), Wilson (1997) and Kilbourne et al. (1998) recorded Gyrochorte from another Carmel Formation locality, Gunlock, in southern Utah. The ichnogenus is very abundant in the grainstones of Member D of Nielson (1990). This member is interpreted as having been deposited in shoal and lagoonal settings. Trace fossils are abundant in the peloid and ooid-rich lagoonal siltstones and grainstones. Together with Gyrochorte, other trace fossils present are Nereites, Asteriacites, Chondrites, Palaeophycus, Monocraterion and Teichichnus.

Gyrochorte has also been found in the Twin Creek Formation near Hanna in northern Utah. Preliminary studies of the locality show that Gyrochorte is rare and occurs in association with Chondrites, Planolites and Phycodes.

\section{CRETACEOUS}

Gyrochorte from Spring Canyon, Utah, belong to the Storrs Member of the Star Point Formation. These deposits represent a deltaic progradational sequence. Gyrochorte occurs in fine to medium-grained sandstone beds on top of mouth bar deposits. These beds may represent sediment reworking on top of the bars. Gyrochorte is very abundant in these beds, and is associated with Planolites, Ophiomorpha irregulaire, Chondrites, and Cylindrichnus. Howard and Frey (1984) studied the ichnology of the Star Point Formation, but they did not mention the presence of Gyrochorte. However, Maberry (1971) reported the presence of the ichnogenus in the overlying Blackhawk Formation.

\section{PLIOCENE}

The Spanish Pliocene Gyrochorte come from the Campredó Blue Clay Unit (informal unit of Arasa, 1990) which records the filling of a small marginal marine bay (Arasa, 1990; Gibert and Martinell, 1996). The Campredó Unit is composed of clays and sandstones deposited in the central and marginal areas of the bay. The body fossil assemblages (mainly mollusk fauna) suggest that salinity conditions were low and were greatly influenced by freshwater input into the bay (Martinell and Domènech, 1984). Gyrochorte occurs in centimeter-thick sandstone beds intercalated with clays. These beds exhibit lowangle cross-stratification and ripples. They are most likely storm beds or storm-induced turbidites (Arasa, 1990). The occurrences are scarce although Gyrochorte is locally abudant in certain beds. Gyrochorte is found in association with Teichichnus, Sinusichnus, and more rarely Nereites and Scolicia (Gibert and Martinell, 1996).

\section{PALEOENVIRONMENTAL AND \\ PALEOECOLOGICAL IMPLICATIONS}

Other published occurrences of Gyrochorte are listed in Table 1, including the paleoenvironment interpreted for each one of them. All the occurrences of actual Gyrochorte are in nearshore and shallow marine deposits. The characteristic setting for the trace is moderate to moderately high energy environments, including bars, shorefaces of beach complexes, storm-dominated shelves and embayment areas. Gyrochorte typically is absent in permanently high energy settings, low energy outer shelves and deep-water environments. In most of the occurrences, Gyrochorte is dominant when it is present and the assemblages commonly exhibit low to moderate diversity. These assemblages are usually composed of shallow-tier traces, mostly pascichnia (such as Planolites, Nereites or Curvolithus), but also fodinichnia (such as Teichichnus, Chondrites or Phycodes) and cubichnia 

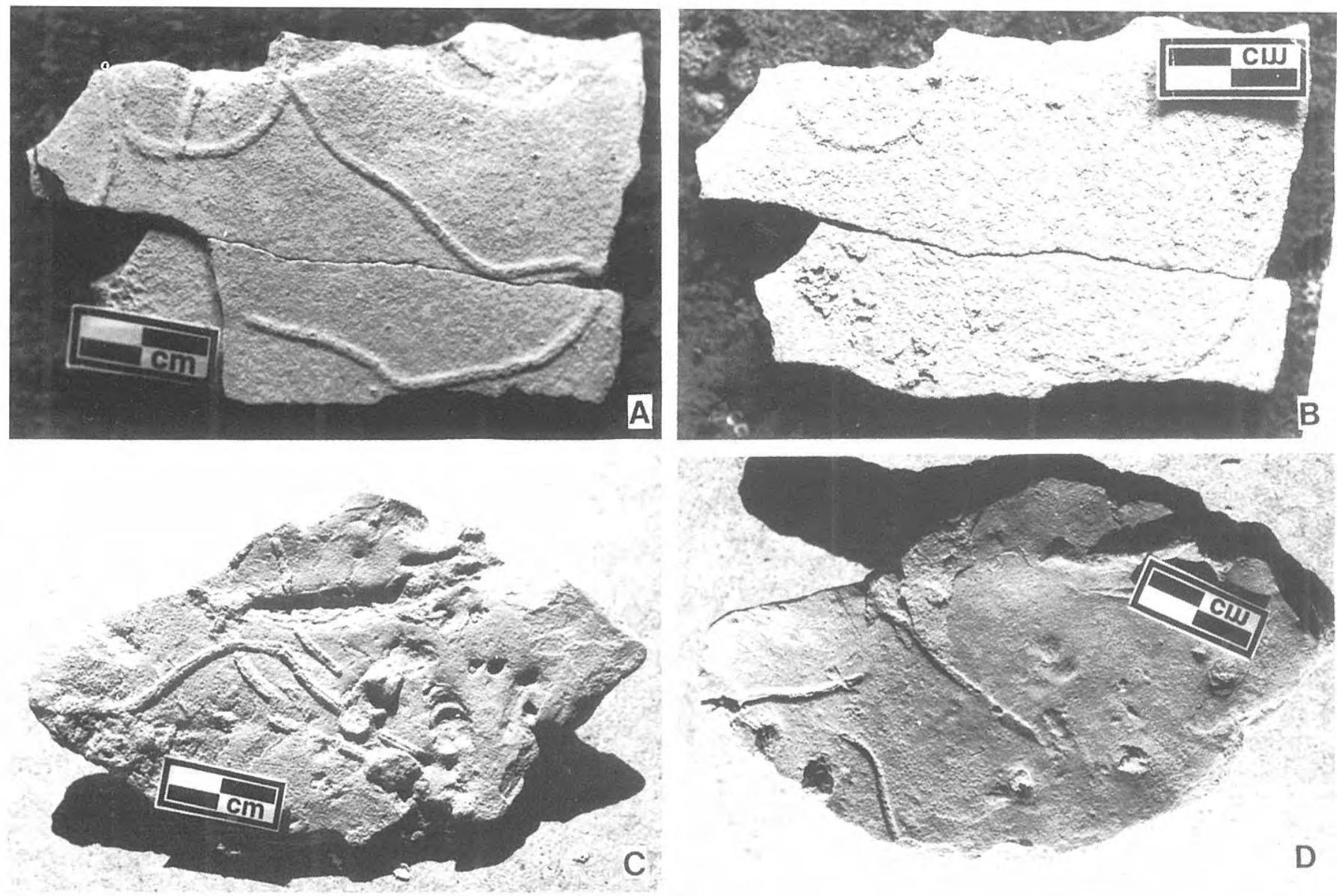

Figure 7. Gyrochorte from the Pliocene of Spain. A-B. Epirelief (A) and corresponding hyporelief (B) (UUIC 1029). C-D. Epirelief (C) and corresponding hyporelief (D). (UUIC 1030) B and D were printed in reverse to orient them in the same manner as $\mathrm{A}$ and $\mathrm{C}$.

(Asteriacites or Lockeia). After the Late Jurassic, crustacean burrow networks (such as Thalassinoides, Ophiomorpha or Sinusichnus) were more commonly associated with Gyrochorte, although in some examples from the literature, it is not clear whether they occur in the same beds. The assemblages containing Gyrochorte are typical of the Cruziana ichnofacies. Hence, although individual trace fossils have to be used cautiously as paleoenvironmental indicators, Gyrochorte assemblages, where this trace fossil is common, can be very good indicators of nearshore and shallow marine environments, especially when considered together with the sedimentology and the associated trace fossils.

Gyrochorte is typically a post-event burrow, suggesting that its producer colonized sandy bottoms during quiet periods between high-energy events (most commonly storms). Powell (1992) suggested that Gyrochorte was a trace produced by an opportunistic animal. Ekdale (1985) indicated that opportunistic ichnotaxa show three main characteristics: 1) they are facies breaking, 2) their occurrences are highly localized (often in high-density isolated occurrences), and 3) the associated assemblages commonly show low diversity. These three points must be considered for Gyrochorte: 1) within its typical setting, Gyrochorte apparently has a great range of tolerance to environmental conditions, including hypersaline (Gibert and Ekdale, 1999) to hyposaline (Hallam, 1970; Gibert and Martinell, 1996) waters; 2) Gyrochorte occurrences usually display high density of the trace fossil; although this could be the result of a single very active animal moving through the sediment, the common occurrence of burrows of different sizes together (e.g., Fig. 3.A) suggests that this was not the case; 3 ) the assemblages containing Gyrochorte range from monospecific (e.g., Powell, 1992) to diverse (e.g., Dam, 1990). Thus, Gyrochorte partly complies with the three conditions pointed out by Ekdale (1985), and it can be considered to be the trace fossil of an opportunistic animal. The common presence of Gyrochorte in association with storm beds also supports the hypothesis that its producer was an opportunistic species adapted to the colonization of newly deposited sandy substrates after high energy depositional events.

\section{CONCLUSIONS}

1. The record of Lower Ordovician and Lower Pliocene Gyrochorte extends its known stratigraphic range at both ends. However, its stratigraphic record is 


\begin{tabular}{||l|l|l||}
\hline \multicolumn{1}{|c|}{ AUTHORS } & \multicolumn{1}{|c||}{ AGE AND LOCATION } & \multicolumn{1}{c||}{ PALEOENVIRONMENT } \\
\hline Gibert \& Martinell 1996, this paper & Lower Pliocene, Spain & bay (low salinity) \\
\hline This paper & Upper Cretaceous, Utah & delta mouth bar \\
\hline Pemberton \& Frey 1984 & Upper Cretaceous, Alberta & storm-influenced shelf \\
\hline Zhou 1997 & Lower Cretaceous, Tibet & shallow marine \\
\hline Heinberg 1973 & Lower Cretaceous, Greeland & shallow marine \\
\hline Badve 1987 & Lower Cretaceous, India & shallow sublittoral \\
\hline Shringarpure 1984 & Jurassic-Cretaceous, India & \\
\hline Howard \& Singh 1985 & Upper Jurassic-Lower Cretaceous, India & nearshore, lagoonal and shallow shelf \\
\hline Poiré 2001 & L. Jurassic-L. Cretaceous, Argentina & storm deposits \\
\hline Schlirf 2000 & Upper Jurassic, France & mid to outer ramp \\
\hline García-Ramos \& Valenzuela 1979 & Upper Jurassic, Spain & coastal to shallow marine \\
\hline Fürsich 1974, 1975 & Upper Jurassic, England and France & shallow marine \\
\hline Kumar 1979 & Upper Jurassic, India & shallow marine \\
\hline Kulkarni \& Ghare 1991 & Middle-Upper Jurassic, India & shallow marine \\
\hline This paper & Middle Jurassic, Utah & shallow marine (hypersaline?) \\
\hline Hallam 1970 & Middle Jurassic, England & marginal marine(low salinity) \\
\hline Fürsich 1998 & Middle Jurassic, India & low to intermediate energy ramp \\
\hline Heinberg \& Birkelund 1984 & Middle Jurassic, Greenland & upper offshore \\
\hline Powell 1992 & Middle Jurassic, England & shoreface \\
\hline Karaszewski 1973 & Middle Jurassic, Poland & shallow marine \\
\hline Weiss 1941 & Middle Jurassic, Germany & \\
\hline Dam 1990 & Lower Jurassic, Greenland & storm-dominated shelf \\
\hline Häntzschel \& Reineck 1968 & Lower Jurassic, Germany & shallow marine \\
\hline Mayer 1980 & Middle Triassic, Germany & \\
\hline Stanley 1994, Stanley \& Pickerill & Late Ordovician, Ontario & storm-dominated shelf \\
\hline 1998 & Lower Ordovician, Utah & storm- dominated subtidal \\
\hline This paper & & \\
\hline
\end{tabular}

Table 1. Reported occurrences of Gyrochorte.

very discontinuous. No Gyrochorte are known between the Ordovician and the Triassic, nor between the Cretaceous and the Pliocene.

2. The identity of the trace maker remains unknown, although it was most likely an annelid.

3. The paleoenvironmental record of Gyrochorte is restricted to moderate energy nearshore and shallow marine environments.

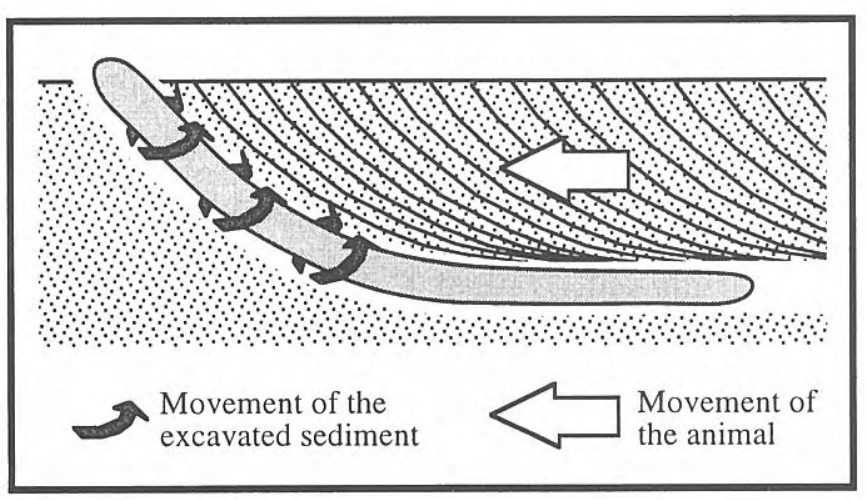

Figure 8. Model for the construction of Gyrochorte by a worm-like animal.
4. Gyrochorte probably was produced by an opportunistic animal colonizing sandy bottoms after high energy event deposition.

\section{ACKNOWLEDGMENTS}

We thank Ben Datillo for showing us the Ordovician locality of Skull Rock Pass and Tony Ekdale for comments and discussion on the manuscript. This paper has been improved thanks to the comments of Jose Carlos García Ramos and Eduardo Mayoral. This work is part of the activities of the Consolidated Research Group 1999SGR00348 of the University of Barcelona and the Research Project BTE 2000-0584 of the Ministerio de Ciencia y Tecnología of Spain. JSB was supported by a Student Grantin-aid from the University of Utah.

\section{REFERENCES}

Arasa, A. 1990. El Terciario del Baix Ebre: aportaciones estratigráficas y sedimentológicas. Acta Geológica Hispánica, 25, 271-288.

Badve, R.M. 1987. A reassessment of stratigraphy of Bagh Beds, Barwah area, Malhya Pradesh, with description of 
trace fossils. Journal of the Geological Society of India, 30, 106-120.

Barnes, R.S.K., Calow, P. and Olive, P.J.W. 1993. The invertebrates: a new synthesis. Blackwell Scientific Publications, Oxford, $488 \mathrm{pp}$.

Benner, J.S. 2000. Ichnology and cyclic stratigraphy of the Lower Ordovician Filmore Formation, Skull Rock Pass, Millard County, Western Utah. M.Sc. Thesis, University of Utah (unpublished), $118 \mathrm{pp}$.

Bromley, R. G. 1996. Trace Fossils: Biology, Taphonomy and Application. Chapman \& Hall, London, 361 pp.

Crimes, T.P., Goldring, R., Homewood, P., van Stuijvenberg, J. and Winkler, W. 1981. Trace fossil assemblages of deep-sea fan deposits, Gurnigel and Schlieren flysch (Cretaceous-Eocene). Eclogae Geologicae Helvetiae, 74, 953-995.

Dam, G. 1990. Palaeoenvironmental significance of trace fossils from the shallow marine Lower Jurassic Neill Klinter Formation, East Greenland. Palaeogeography, Paleoclimatology, Palaeoecology, 79, 221-248.

Datillo, B. F. 1993. The Lower Ordovician Filmore Formation of Western Utah: storm-dominated sedimentation on a passive margin. Brigham Young University Geology Studies, 39, 71-100.

Dinamani, P. 1964. Burrowing behavior of Dentalium. Biological Bulletin, 16, 28-32.

Ekdale, A. A. 1985. Palaeoecology of the marine endobenthos. Palaeogeography, Paleoclimatology, Palaeoecology, 50, 63-81.

Fenton, C. L. and Fenton, M. A. 1937. Burrows and trails from Pennsylvanian rocks of Texas. American Midland Naturalist, 18, 1079-1084.

Frey, R.W. and Chowns, T.M. 1972. Trace fossils from the Ringglod road cut (Ordovician and Silurian), Georgia. In: Sedimentary environments in the Paleozoic rocks of north western Georgia, Guidebook Georgia Geological Society, 11, 25-44.

Fuchs, T. 1895. Studien über Fukoiden und Hieroglyphen. Denkschriften der Akademie der Wissenschafter Wien, Mathematisch-Naturwissenschaftliche Klasse, 62, 369448.

Fürsich, F. T. 1974. Corallian (Upper Jurassic) trace fossils from England and Normandy. Stuttgarter Beitrage zur Naturkunde, Serie B, 13, 1-51.

Fürsich, F. T. 1975. Trace fossils as environmental indicators in the Corallian of England and Normandy. Lethaia, 8, 151-172.

Fürsich, F. T. 1998. Environmental distribution of trace fossils in the Jurassic of Kachch (Western India). Facies, 39, 243-372.

García-Ramos, J. C. y Valenzuela, M. 1979. Estudio e interpretación de la icnofauna (vertebrados e invertebrados) en el Jurásico de la costa asturiana. Cuadernos de Geología, Universidad de Granada, 10, 13-22.

Ghare, M. A. and Kulkarni, K. G. 1986. Jurassic ichnofauna of Kutch - II: Wagad region. Biovigyanam, 12, 44-62.

Gibert, J. M. de and Ekdale, A. A. 1999. Trace fossil assemblages reflecting stressed environments in the Middle Jurassic Carmel Seaway of Central Utah. Journal of Paleontology, 73, 711-720.
Gibert, J.M. de and Ekdale, A.A. (in press). Ichnology of a restricted epicontinental sea, Arapien Shale, Middle Jurassic, Utah, U.S.A. Palaeogeography, Palaeoclimatology, Palaeoecology.

Gibert, J. M. de and Martinell, J. 1996. Trace fossil assemblages and their palaeoenvironmental significance in the Pliocene marginal marine deposits of the Baix Ebre (Catalonia, Spain). Géologie Méditerranéenne, 23, 211-225.

Hakes, W. G. 1976. Trace fossils and depositional environment of four clastic units, Upper Pennsylvanian megacyclothems, northeast Kansas. University of Kansas Paleontological Contributions, 63, 1-46.

Hallam, A. 1970. Gyrochorte and other trace fossils in the Forest Marble (Bathonian) of Dorset, England. In: Trace fossils (Eds. T. P. Crimes and J. C. Harper), Geological Journal Special Issue, 3, Liverpool, 189-200.

Hancock, A. 1858. Remarks on certain vermiform fossils found in mountain limestone districts of the North of England. Annual Magazine of Natural History (3), 2, 443.

Häntzschel, W. 1975. Treatise on Invertebrate Paleontology, Part $W$, Trace fossils and problematica. Geological Society of America and University of Kansas Press, Lawrence, 269 pp.

Häntzschel, W. und Reineck, H. E. 1968. Fazies Untersuchungen in Hettangium von Helmstedt (Niedersachen). Geologisch Staatsinstitut Hamburg, Mitteilungen, 37, 5-39.

Heer, O. 1865. Die Unwelt der Schweiz. F. Schulthess, Zurich, $622 \mathrm{pp}$.

Heinberg, C. 1973. The internal structure of the trace fossils Gyrochorte and Curvolithus. Lethaia, 6, 227-238.

Heinberg, C. and Birkelund, T. 1984. Trace-fossil assemblages and basin evolution of the Vanderkløft Formation (Middle Jurassic, East Greenland). Journal of Paleontology, 58, 362-397.

Hintze, L. F. 1951. Lower Ordovician detailed stratigraphic sections for western Utah. Utah Geological and Mineralogical Survey Bulletin, 39, 1-100.

Hintze, L. F. 1973. Lower and middle Ordovician stratigraphic sections in the Ibex area, Millard County, Utah. Brigham Young University Geology Studies, 20, 336.

Hintze, L. F. 1988. Geologic History of Utah. Brigham Young University, Provo, 202 pp.

Howard, J. D. and Frey, R. W. 1984. Characteristic trace fossils in nearshore to foreshore sequences, Upper Cretaceous of East-Central Utah. Canadian Journal of Earth Sciences, 21, 200-219.

Howard, J. D. and Singh, I. B. 1985. Trace fossils in the Mesozoic sediments of Kachchh, Western India. Palaeogeography, Palaeoclimatology, Palaeoecology, 52, 99-122.

Imlay, R. W. 1980. Jurassic paleobiogeography of the conterminous United States in its continental setting. U.S. Geological Survey Professional Paper, 1062, 1-121.

Karaszewski, W. 1973. Rhizocorallium, Gyrochorte and other trace fossils from the Middle Jurassic of the Inowlódz Region, Middle Poland. Bulletin de l'Académie 
Polonaise des Sciences, Série des Sciences de la Terre, 21, 199-204.

Kilbourne, K. H., Curran, H. A. and Wilson, M. A. 1998. Ichnocoenoses and paleoenvironments of the Middle Jurassic Carmel-Twin Creek Seaway (Carmel Formation, southwestern Utah). 1998 AAPG Annual Convention, A357.

Ksiazkiewicz, M. 1970. Observations on the ichnofauna of the Polish Carpathians. In: Trace fossils (Eds. T. P. Crimes and J. C. Harper), Geological Journal Special Issue, 3, Liverpool, 282-322.

Ksiazkiewicz, M. 1977. Trace fossils in the flysch of the Polish Carpathians. Palaeontologica Polonica, 36, 1-208.

Kulkarni, K. G. and Ghare, M. A. 1991. Locomotory traces (Repichnia) from the Jurassic sequence of Kutch, Gujarat. Journal of the Geological Society of India, 37, 374-387.

Kumar, A. 1979. A report on the occurrence of Gyrochorte and other bilobed trace fossils from the Jaisalmer Formation, Rajasthan. Current Science, 48, 817-818.

Lord, G. D. 1985. Stratigraphy, petrography and depositional environments of the Twin Creek LimestoneArapien Shale, northern and central Utah. Unpublished, M.Sc. Thesis, University of Utah, $87 \mathrm{pp}$.

Maberry, J. O. 1971. Sedimentary features of the Blackhawk Formation (Cretaceous) in the Sunnyside County, Utah. Geological Survey Profesional Paper, 688, 1-19.

Macsotay, O. 1967. Huellas problemáticas y su valor paleoecológico en Venezuela. Geos, 16, 1-79.

Martinell, J. y Domènech, R. 1984. Malacofauna del Plioceno de Sant Onofre (Baix Ebre: Tarragona). Iberus, 4, 1-17.

Mayer, G. 1980. Eine Zopfplatte aus dem Unteren Hauptmuschelkalk von Nussloch (Kraichgan). Jahreshefte der gesellschaft fur Naturkunde in Wuerttemberg, 135, 173-176.

McDowell, R. R. 1988. Middle Ordovician Kanosh Formation. Remaining source-rock potential? The Mountain Geologist, 25, 141-158.

Nielson, D. R. 1990. Stratigraphy and sedimentology of the Middle Jurassic Carmel Formation in the Gunlock area, Washington County, Utah. Brigham Young University Geology Studies, 36, 153-192.

Pemberton, S. G. and Frey, R. W. 1984. Ichnology of storminfluenced shallow marine sequence: Cardium Formation (Upper Cretaceous) at Seebe, Alberta. In: The Mesozoic of Middle North America (Eds. D. F. Stott and D. J. Glass). Canadian Society of Petroleum Geologists Memoir, 9, 281-304.

Picard, M. D. and Uygur, K., 1982. Mixed terrigenouscarbonate rocks in Jurassic Arapien Shale of central Utah. In: Overthrust Belt of Utah (Ed. D. L. Nielson). Utah Geological Association Publication, 10, 181-198.

Pickerill, R. K. 1980. Phanerozoic flysch trace fossil diversity - observations based on an Ordovician flysch ichnofauna from the Aroostook - Matapedia Carbonate Belt of northern New Brunswick. Canadian Journal of Earth Sciences, 17, 1259-1270.

Pickerill, R. K. 1994. Nomenclature and taxonomy of invertebrate trace fossils. In: The Palaeobiology of Trace
Fossils (Ed. S. K. Donovan). John Wiley \& Sons, Chichester, 3-42.

Poiré, D.G. 2001. Gyrochorte as trace fossil indicator of storm events in the Neuquén Basin, Argentina. 2001 AAPG Annual Convention, A159.

Pollard, J.E. 1988. Trace fossils in coal-bearing sequences. Journal of the Geological Society, London, 145, 339. 350 .

Powell, J.H. 1992. Gyrochorte burrows from the Scarborough Formation (Middle Jurassic) of the Cleveland Basin, and their sedimentological setting. Proceedings of the Yorkshire Geological Society, 49, 4147.

Ronan, T. E. 1977. Formation and paleontologic recognition of structures caused by marine annelids. Paleobiology, $\mathbf{3}$, 389-403.

Schäfer, W. 1972. Ecology and palaeoecology of marine environments. Oliver \& Boyd, Edinburgh, 568 pp.

Schlirf, M. 2000. Upper Jurassic trace fossils from the Boulounnais (northern France). Geologica et Paleontologica, 34, 145-213.

Seilacher, A. 1954. Die geologische Bedeutung fossiler Lebensspuren. Deutsch Geologische Gesellschaft, Zeitschrift, 105, 213-227.

Seilacher, A. 1955. Spuren und Fazies im Unterkambrium. In: Beiträge zur Kenntnis des Kambriums in der Salt Range (Pakistan) (Eds. O. Schindewolf and A. Seilacher). Akademie der Wissenschaften und der Literature Mainz, Mathematisch-Naturwissenschaftlichen Klasse, Abhandlungen, 10, 117-143.

Seilacher, A. 1963. Lebensspuren und Salinitätsfazies. Fortschritte Geologie von Rheinland uber Westfalen, 10, 81-94.

Seilacher, A. and Alidou, S. 1998. Ordovician and Silurian trace fossils from Northern Benin (W-Africa). Neues Jahrbuch für Geologie und Paläontologie Monatshefte, 1998, 431-439.

Shringarpure, D. M. 1984. Mesozoic of Kutch (India); Middle Jurassic to Lower Cretaceous depositional environments as revealed by biosedimentary structures. In: Third Symposium on Mesozoic terrestrial ecosystems, short papers (Eds. W. E. Reif and F. Westphal). Tubingen, 227-230.

Smail, S.E. and Wilson, M. A. 1993. Detailed ichnology of a Middle Jurassic shallowing-upward marine sequence in the Carmel Formation, south western Utah, USA. Geological Society of America Abstracts with Programs, 25, 270 .

Stanley, D. C. A. 1994. Systematic ichnology of the Late Ordovician Georgian Bay Formation of Southern Ontario, Canada. Unpublished, M.Sc. Thesis, University of New Brunswick, Canada, 258 pp.

Stanley, D. C. A. and Pickerill R. K. 1998. Systematic ichnology of the Late Ordovician Georgian Bay Formation of Southern Ontario, Eastern Canada. Royal Ontario Museum, Life Sciences Contributions, 162, 1-55.

Uchman, A. 1998. Taxonomy and ethology of flysch trace fossils: revision of the Marian Ksiazkiewicz collection and study of complementary material. Annales Societatis Geologorum Poloniae, 68, 105-218. 
Walter, M. R., Elphinstone, R. and Heys, G. R. 1989. Proterozoic and Early Cambrian trace fossils from the Amadeus and Georgina Basins, central Australia. Alcheringa, 13, 209-256.

Weiss, W. 1941. Die Entstehung der 'Zöpfe' im Schwarzen und Braunen Jura. Natur und Volk, 71, 179-184.

Wilson, M. A. 1997. Trace fossils, hardgrounds and ostreoliths in the Carmel Formation (Middle Jurassic) of southwestern Utah. In: Mesozoic to Recent Geology of Utah (Eds. P. K. Link and B. J. Kowallis). Brigham Young University Geology Studies, 42, part II, 6-9.

Zhou, Z. 1997. Cretaceous and Lower Tertiary trace fossils from the Gamaba area of Southern Tibet, China. Neues Jahrbuch fur Geologie und Paläontologie Abhandlungen, 203, 145-172.

Manuscrito recibido: 6 de marzo, 2001 Manuscrito aceptado: 4 de septiembre, 2001

\section{APPENDIX 1: LOCALITIES}

\section{Skull Rock Pass}

This site is located in the southern part of the House Range, approximately about $70 \mathrm{~km}$ southwest of the town of Delta, in western Utah. The section corresponds to the informal "light-gray ledge forming member" (Hintze, 1951, 1973 ) of the Lower Ordovician Fillmore Formation (Ibexian, equivalent to the Upper Tremadoc-Lower Arenig following Hintze, 1988).

\section{Fossil Mountain}

Fossil Mountain is located in the southeastern part of the Confusion Range, about $24 \mathrm{~km}$ southwest of Skull Rock Pass in western Utah. Gyrochorte was found in the Lower Ordovician Kanosh Shale Formation (lower Whiterockian, equivalent to the Upper Arenig following Hintze, 1988).

\section{Nephi}

Gyrochorte occurs in the Middle Jurassic Arapien Shale (Bathonian-Callovian) in Salt Creek Canyon, which is located west of the town of Nephi in central Utah.

\section{San Rafael Swell}

The specimens were obtained from the Middle Jurassic Carmel Formation (Bajocian-Bathonian) on the western side of the San Rafael Swell in central Utah. The studied outcrops are located in the intersection between Highway I70 and a small dirt road known as the Moore road.

\section{Gunlock}

A few specimens were collected from the Carmel Formation (Bajocian-Bathonian, Middle Jurassic) in the Beaver Dam Mountains west of Gunlock in southern Utah.

\section{Hanna}

The section of the Twin Creek Limestone (BajocianBathonian, Middle Jurassic) in the town of Hanna in the southern Uintah Mountains, northern Utah, also provided a few specimens of Gyrochorte.

\section{Spring Canyon}

The Storrs Member of the Star Point Formation (Campanian, Upper Cretaceous) has yielded abundant specimens of Gyrochorte in Spring Canyon, west of Helper in central Utah.

\section{Sant Onofre}

The locality of Sant Onofre is located in a clay quarry about $15 \mathrm{~km}$ south of Tortosa (province of Tarragona, Spain). Gyrochorte was found in the informal Campredó Blue Clay Unit of Arasa (1990) (Zanclean, Lower Pliocene). 